NBER WORKING PAPER SERIES

PROTECTIONIST PRESSURES, IMPORTS, AND

EMPLOYMENT IN THE UNITED STATES

Anne 0 . Krueger

Working Paper No. 461

NATIONAL BUREAU OF ECONOMIC RESEARCH

1050 Massachusetts Avenue

Cambridge MA 02138

March 1980

I am indebted to James $M$. Henderson for helpful discussions on the subject matter of this paper, and to Paitoon Wiboonchutikula for research assistance. The empirical results reported in Section II are drawn from Krueger (1979a and $1979 \mathrm{~b}$ ). The research reported here is part of the NBER's program in International Studies. Any opinions expressed are those of the author and not those of the National Bureau of Economic Research. 


\title{
Protectionist Pressures, Imports, and Employment. in the United States
}

\begin{abstract}
This paper assesses the theoretical and empirical basis for American labor union leaders' contention that imports have been a big source of job loss in the United States. It is shown, first, that identification of job losses "due to imports" is exceptionally difficult bezause economic growth affects adversely the industries believed affected by imports. Then, an accounting framework is employed to assess possible empirical orders of magnitude. The results are fairly conclusive in indicating that factors other than import competition have been primary in leading to structural shifts in employment.
\end{abstract}

Professor Anne 0 . Kreuger Department of Economics University of Minnesota 1035 Business Administration Building 271 19th Avenue South Minneapolis, MN 55455

(612) $373-3655$ 


\section{PROTECTIONIST PRESSURES, INPORTS, AND ENPLOYMENT}

IN THE UNITED STATES

Anne 0. Krueger*

The American labor movement reversed its support of frec trade in the 1960s, claiming and believing that "American jobs are lost" as a consequence of import competition. Its switch to a protectionjst: stance has been a significant force in American political discussions regarding trade policy. There can be little doubt that American adoption of such protectionist measures as trigger pricing for steel and the multifiber agreement was, in substantial measure, a consequence of labor pressures and the view of many other Americans that American labor was essentially correct in its beliefs. Advocates of free trade felt compelled to support "adjustment" assistance to "import-impacted workers" as part of their case.

It is the purpose of this paper to review the theory and empirical evidence underlying the view that job losses have, in some sense, resulted from import competition. The basic message is that, at lcast for the Onited States, it is exceptionally difficult to make an argument that job losses, however defined, have been "caused", in any substantial part, by import competition. A first section briefly sets forth conventional theory as to the possible relationship between imports and

\footnotetext{
* Professor of Economics, University of Minnesota. I am indebted to James M. Henderson for helpful discussions on the subject matter of this paper, and to Paitoon Wiboonchutikula for research assistance. The empirical results reported in Section II are drawn from Krueger (1979a and 1979b). Any opinions expressed are those of the author and not those of the National Bureau of Economic Research.
} 
employment. A second section sets forth some empirical evidence about the changing composition of employment in U.S. manufacturing industry and the proximate decomposition of those changes into those ganerated by demand patterns, by productivity growth, and by imports or the net trade balance. A final section provides some indication as to the relative importance, within several allegedly trade-impacted industries, of gross and net employment changes in determining layoffs, and examines briefly the question of who gains, and who loses, in industries receiving protection.

\section{HOW CAN IMPORTS AFFECT EMPIOYMENT?}

Different economic theories have varying models of the underlying determinants of employment and wage determination. None of them assigns to imports (contrasted with the trade balance) a central role in the determination of employment.

At one extreme lies neoclassical theory, in which wages are fully flexible, so that the number of persons employed is a function of demand for, and supply of, labor. Any shift in the demand curve for Jabor is associated with a change in employment only insofar as the labor supply curve is not perfectly inelastic. When the demand curve for labor shifts upward, employment increases or decreases as the labor supply curve is forward sloping or backward bending. In the neoclassical model, import competition could affect employment and/or the real wage via the StolperSamuelson effect, with free trade resulting in a downward or upward shift in demand for labor, depending upon the relative factor intensity of imports and exports. If, as Leontief, Baldwin, Branson and Monoyios 
and others have found American exports are relatively labor-intensive contrasted with American imports, theory would suggest that free trade would result in a higher real wage than would protection, and employment would be greater or less with free trade depending upon the sign of the slope of the labor supply curve.

At the opposite end of the spectrum is the simple IS-IM Keynesian model, in which the real wage is exogenously determined (via the price level or other means), and the level of aggregate demand determines the level of employment. In the model, fiscal and monetary policy determine the level of employment, and changes in imports are significant only insofar as they are not accompanied by changes in exports.

What all these models have in common is that they treat the Jevel of employment as a macroeconomic phenomenon which, in the aggregate, it surely is. In addition, one cannot associate increases in imports with job losses unless one extends the analysis to take into account both the general equilibrium repercussions of the net increase in exports that would accompany any change in imports and also the underlying nature of the labor market (and in particular whether changes in the demand for labor are likely to be reflected in changes in the nominal or real wage rate). It is thus apparent that one cannot legitimately view imports, or changes in import levels, as a significant determinant of aggregate employment.

What may make sense, however, is to examine "impact effects" on different industries of the changing pattern of trade. For, while aggregate employment levels are surely a function more of macroeconomic variables than of trade flows, it can be contended that import competition causes some individuals and firms to relocate either geographically or sectorally 
and that such relocation may cause hardships. If one is to make economic sense out of demands for protection on grounds of the "employment" effect of imports, it must surely be these "impact" effects, and the short-tern dislocations that individual industries may suffer, that are the source of concern. 1

Even here, however, there are significant, and important, difficulties. For, as is well known, there are many causes of changes in employrnent: composition. Changes in tastes and other random factors can result in an altered distribution of output and employment. Competitive successes and failures lead to changing patterns within, as well as between industries. Perhaps even more important, the process of economic growth generates systematic changes in patterns of employment and output. This is both because: 1) income elasticities differ from unity, and employment must. therefore shift from low-income-elasticity goods to high income-elasticity goods if the process of economic growth is to continue, and 2) factor accumulation, and especially accumulation of physical and human capital, alters the relative scarcity of different factors of production. As that happens, the real wage accruing to unskilled labor" rises,white the real return to capital and skills falls relative to the return to unskilled labor. The change in relative factor prices, in turn, alters the relative costs of production in different Iines, thus altering relative prices of final goods (unless, by chance, technological changes proceeds faster in relatively unskilled labor-intensive industries), and inducing consumers to substitute capital-and skill-intensive goods

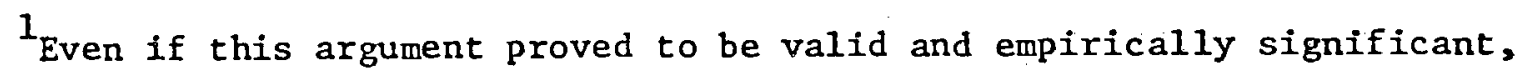
it would not constitute a convincing case for protection: The permanent consumption losses associated with failing to adjust would have to be evaluated against the short-term "gains" that stemed from avoiding dislocation costs. On the size of those costs in the U.S., see Bale. 
for unskilled-labor intensive goods in their consumption basket. 1

That change must occur in the process of economic growth is widely accepted. Indeed, it would not be possible for rapid-growth industries to expand unless resources were released from contracting industries, and resistances to those changes would, by definition, retard the growth process. For present purposes, however, a major difficulty arises: for advanced countries such as the United States, the same labor-jintensive industrles that are likely to contract relatively because of rising real wages are the ones where import competition is most likely to be felt. This follows naturally from the factor proportions explanation of trade ${ }^{2}$ : just as industries intensive in the use of unskilled labor are likely to be slowly growing because of their cost disadvantage with rising real wages, those same industries are likely to be at a competitive disadvantage vis-a-vis competition from imports, since the comparative advantage of the U.S. (and other advanced countries) is likely to lie in capital and skill-intensive goods.

Thus, the fact that the number of jobs in a certain labor-intensive Industry may be declining is not per se evidence that imports are the "cause". To the extent that the foreign supply curve remains constant. through the process, there is some presumption that the decline in employ-ment is primarily a consequence of rising real wage rates and the process of reallocation of labor towards higher value-adding industries. In fact,

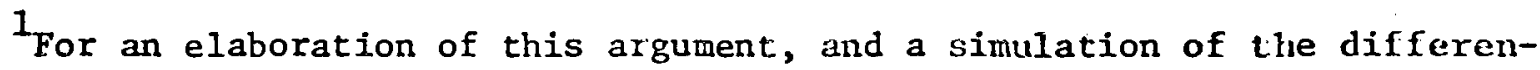
tial employment impact of capital deepening on labor-and capital-intensive industries, see Krueger (1979b).

2 Note, however, that it is not consistent with the leontief finding that U.S. exports are capital-intensive relative to U.S. imports. 
if the foreign supply curve of imports is constant over time, it would be difficult to attribute employment declines to "import competition": at most, a case could be made that the presence of import competition prevented the domestic price from increasing as rapidly as it: otherwise would have. In that sense, imports permit higher domestic consumption levels of labor-intensive goods than would othertise be possible. Only a part of imports can be regarded as replacing domestic output: in consumption。

The preceeding paragraph points up a major conceptual difficulty in attempting to estimate the "employment losses" attributabie to imports: quite aside from general equilibrium problems, appropriate estimation would entail the specification of domestic demand and supply functions, and in addition would require estimation of the extent to which imports in a particular category increased moving along a foreign supply curve and the extent to which they rose because of shifts in forejgn supply curves. ${ }^{1}$

It is these considerations which motivate the method of measurement used in the next section: Because of the deep-seated difficulties in identifying the extent to which it is factors associated with economic growth or it is imports that affect employment opportunities in laborintensive industries, an accounting framework is instead employed.

1 There is another difficulty with the "imports cause job losses" argument: insofar as the domestic supply of import-competing goods is inelastic, increased imports would be met by a lower domestic price, with employment fairly constant. It is only if the supply curve of domestic labor-intensive goods is fairly elastic that one can argue sensitivity to foreign competition. But an elastic domestic supply presumably implies alternative uses of the factors of production. 


\section{ACCOUNTING FOR THE SECTORAL COMPOSITION OF AMERICAN MANUFACTURING EMPLOYMENT CHANGES, 1970 to 1976}

The period 1970 to 1976 was chosen for analysis for several reasons. On one hand,Frank has already analyzed the import-employment relation for the period 1963 to 1971, finding that the AFL-ClO claims for the impact of import levels on employment were greatiy exaggerated and that, even for the three-digit industries for which imports were either laxgest or had grown most rapidly, rates of growth of demand and of labor productivity were significantly larger than import growth in affecting rates of change of employment. For present purposes, the year 1970, rather 1971, was chosen as an initial year for several reasons: 1) the existence of: Frank's work covering the 1960s; 2) 1970 marked the year before dollar. devaluation and is often pinpointed as the time when the large increase in imports started; and 3) because dollar devaluation took place in the middle of 1971, price statistics for 1971 to 1976 are somewhat Jess reliable than those for 1970 to 1976.

The choice of 1976 for a terminal year was affected by several factors: 1) it was the latest year for which data were available as of the time the computations were undertaken; 2) it was still a year of less-than full-employment in the United States, so that concern with jobs and employment opportunities was perhaps better focused than was the case in the years 1977 and 1978 when the overall unemployment rate was lower; and 3) the price adjustments of 1974 and 1975 had had a chance to work their way through the system, so that data for 1976 may better reflect underlying long-term factors than data for earlier years. It should be noted also that the 1970 s were the period during which concern about import 
competition from the LDCs has been intense: focus upon the 1970-16 period should therefore enable a judgment as to its validity. 1

Form the identity

$$
c_{i t} \equiv Q_{i t}-X_{i t}+M_{i t}
$$

where $C_{i t}$ is domestic utilization (for final private consumption, interindustry demand, inventory accumulation, other investment, and government use) of the ith good in period $t$, $Q$ is domestic output, $X$ is exports, and $M$ is imports. All variables are measured in constant base-period prices. At any time $t$, labor has an average productivity:

$$
\frac{Q_{i t}}{L_{i t}} \equiv a_{i t}
$$

where $L_{i t}$ is employment in the $i$ th industry or sector and $a_{j t}$ fs the average product of labor.

Define $S_{t}$ as the ratio of domestic output to domestic consumption $\left(S_{t} \equiv Q_{t} / C_{t}\right)$ and assume that the domestic share of output in consumption, S, labor productiviey, a, and domestic utilization all grow (or decline) at constant continuous rates:

$$
\begin{aligned}
& s_{t}=s_{0} e^{\alpha t} \\
& a_{t}=a_{0} e^{\rho t} \\
& c_{t}=c_{0} e^{\beta t}
\end{aligned}
$$

${ }^{1}$ It should be noted, however, that the IDC share of imports into the OECD countries remained relatively small in 1976 and subsequent years. Manufactured exports from developing to industrialized countries in 1976 constituted 9.9 percent of total manufactured imports by industrialized countries, and only 1.6 percent of consumption of manufactured products in developed countries. See World Bank, World Development Report 1979, P. 21 . 
$s_{0}, s_{t}, a_{0}, a_{t}, c_{0}$ and $c_{t}$ can all be ascertained from initial-year and terminal values, thus yielding solutions for the three rates of growth.

Employment, $L_{t}$, can then be expressed as:

$$
\begin{aligned}
I_{t} & =a_{t}^{-1} S_{t} C_{t}=a_{0}^{-1} e^{-\rho t} S_{0} e^{\alpha t} C_{0} e^{\beta t} \\
& =E_{0} e^{(\beta+\alpha-\rho) t}
\end{aligned}
$$

The rate of growth of employment is thus expressed as the sum of three components: the growth rate of domestic consumption, 1 the growth rate of the share of domestic output in domestic consumption, and (ninus) the growth rate of labor productivity. ${ }^{2}$ A negative sign for $\alpha$, for example, Indicates that the share of domestic consumption net by domestic production declined, and $\alpha$ can be interepreted as the additional continuous rate of growth in employment that would have been attained had the share of domestic output in domestic consumption remained constant, ALL ELSE UNCHANGED. For reasons spelled out above, it is not at all evident that all else would have remained unchanged, so that the interpretation of $\alpha$ must be pureily definitional. In a closed economy, $\alpha$ would be zero by definition. However, the growth rates $\beta$ and $p$ would very likely be different, even given the same underlying tastes,

${ }^{1}$ Domestic consumption is defined alternatively as domestic production plus imports (which implicitly includes exports as part of domestic demand) and domestic production plus imports less exports. Comparison of the two sets of results permits a contrast between the gross sectoral. effect and the net effect.

${ }^{2}$ Alternatively, one could compute time trends from regression equations and use them to calculate rates in Equation (6). The difficulties of gathering the data precluded such an effort. 
production functions and factor endowments as in the open economy case. $^{1}$

Using these relations, data were collected for 1970 and 1976. Despite the apparent simplicity of the accounting fxamework, there is nothing simple about data collection: trade statistics are on a commodity basis, output and employment statistics are on an industry basis, and price statistics are compiled on yet a third basis. Considerable effort is involved in reconciling these three groups of data.

Table 1 gives the continuous rates of growth of consumption (utilization), labor productivity, imports, the net trade balance, and employment derived by the procedures described above. By definition, the sum of the first three colums equals the last colum. For non-electrical machinery, for example, the rate of growth of domestic utilization (defined as domestic consumption plus imports) was $2.8 \mathrm{x}$ percent continuously, while labor productivity grew .54 percent and the share of domestic output in domestic utilization fell at a continuous rate of .32 percent: Eroployment grew at an annual average rate of 1.95 percent (equal to 2.81 minus .54 minus .32). To state 1 t another way: had imports grown at: the same rate as domestic production while domestic utilization and labor productivity followed their actual growth paths, employment would have increased at a continuous rate .32 percent faster than the realized one. If net trade

${ }^{1}$ It should be noted that $\beta$ cannot be interpreted simply as the rate of upward shift in the demand curve: whatever price changes occurred during the period under analysis would affect the estimated rate of growth of utilization, and $\beta$ links observed utilization levels. Only if price had remained unchanged would $\beta$ reflect the rate of upward shift of the dernand curve. Even then, the rate of growth of real income might well differ in a closed economy, so that $\beta$ would differ on that reason.

2 The interested reader is referred to Krueger (1979a) for particulars with regard to the data sources. Obtaining reliable price deflators is perhaps the most difficult task, but any errors in those estimates are reflected in both labor productivity and demand, and thus do not affect the estimate of $\alpha$. Printing and publishing was omitted for lack of an appropriate price index. 
Table 1

U.S. Rates of Growth of Demand, Labor Productivity,

Import Share and Employment, 1970 to 1976

(continuous percentage rates)

\section{Industry}

\begin{tabular}{lccccc} 
& \multicolumn{3}{c}{ Labor } & \multicolumn{3}{c}{ Net Trade } \\
SIC & Demand & Produc- & & Balance \\
Gode Name & Growth & tivity & Imports & $(=X-M)$ & Employment \\
& $(1)$ & $(2)$ & $(3)$ & $(4)$ & (5)
\end{tabular}

\begin{tabular}{|c|c|c|c|c|c|c|}
\hline 20 & Food Products & 1.30 & -1.68 & -.02 & -.13 & -.41 \\
\hline 21 & Tobacco Products & 1.32 & -1.78 & -.05 & -.38 & -.51 \\
\hline 22 & Textile Mill Products & -.20 & -.47 & .09 & .43 & -.58 \\
\hline 23 & Apparel & 3.03 & -2.68 & -.96 & -.77 & -.62 \\
\hline 24 & Lumber Products & -1.16 & 4.20 & -.18 &. .19 & 2.85 \\
\hline 25 & Furniture \& Fixtures & 1.41 & -1.56 & -.24 & .09 & -.39 \\
\hline 26 & $\begin{array}{l}\text { Paper \& Paper Prod- } \\
\text { ucts }\end{array}$ & 2.16 & -2.48 & -.13 & -.01 & -.45 \\
\hline 28 & Chemicals & 1.80 & -1.56 & -.20 & -.08 & .04 \\
\hline 29 & $\begin{array}{l}\text { Petroleum \& Coal } \\
\text { Products }\end{array}$ & 2.68 & -1.78 & -.43 & .59 & .47 \\
\hline 30 & $\begin{array}{l}\text { Rubber \& Plastic } \\
\text { Products }\end{array}$ & 3.87 & -1.20 & -.30 & -.06 & 2.37 \\
\hline 31 & Leather Products & -.60 & .38 & -1.51 & -1.27 & -2.1 .73 \\
\hline 32 & $\begin{array}{l}\text { Stone, Clay \& Glass } \\
\text { Products }\end{array}$ & .18 & .38 & -.11 & -.05 & .45 \\
\hline 33 & Primary Metals & .01 & -.79 & -.23 & -.42 & -.92 \\
\hline 34 & $\begin{array}{l}\text { Fabricated Metal } \\
\text { Products }\end{array}$ & 2.32 & .17 & -.16 &. .18 & 2.33 \\
\hline 35 & $\begin{array}{l}\text { Non-Electric Mach- } \\
\text { inery }\end{array}$ & 2.81 & -.54 & -.32 & -.55 & 1.95 \\
\hline 36 & $\begin{array}{l}\text { Electrical \& Elec- } \\
\text { tronic Equipment }\end{array}$ & 2.20 & -2.12 & -.90 & -.14 & -.82 \\
\hline 37 & $\begin{array}{l}\text { Transportation Equip- } \\
\text { ment }\end{array}$ & -2.04 & -.92 & -.64 & -.23 & .48 \\
\hline $\begin{array}{l}38 \\
39\end{array}$ & $\begin{array}{l}\text { Instruments } \\
\text { Miscellaneous } \\
\text { Manufacturing }\end{array}$ & $\begin{array}{l}7.75 \\
2.66\end{array}$ & $\begin{array}{l}-2.12 \\
-2.12\end{array}$ & $\begin{array}{l}-.56 \\
-.58\end{array}$ & $\begin{array}{r}-.28 \\
.01\end{array}$ & $\begin{array}{l}5.08 \\
-.04\end{array}$ \\
\hline
\end{tabular}

Source: Department of Commerce Bureau of the U.S. Census, U. S. Commodity Exports and Imports as Related to Output 1970 and 1969 and 1976 and 1975 . Annual Survey of Manufactures, 1970 and 1976. Output and trade data for 1976 were deflated by the Department of Commerce 2-digit SIC deflators contained in Wholesale Prices and Price Indices Data for January 1977, Data for January 1971, and December 1976 figures were used. 
balance, rather than irports, is used, employment and labor productivity growth rates are unaffected. Thus, "true" domestic utilization can be derived by adding the difference between the trade balance rate and the import rate to the domestic demand growth rates. For example, for electrical and electronic equipment the import share decreased at a rate of -.90 percent while the share of the net trade balance declined at a rate of -.14 percent. Thus, part of the increase in imports was offset by growth of exports, and the growth of domestic utilization, defined as $Q+M-X$, was 1.44 percent annually $(2.20-.90+.1 .4)$. Examination of the data in Table 1 suggests that rates of change in domestic demand and labor productivity were quantitatively larger than the rate of growth of import share in all two digit sectors except for leather, even without taking into account the behaviox of exports in the same sectors. Moreover, in only three sectors - electrical and electronic equiprent, apparel, and miscellaneous manufactures - in which employment declined could employment have grown with a constant import share even if demand and labor productivity had followed their actual course. These conclusions emerge even more strongly if the net trade balance colum, rather than the import column, is examined. For niscellaneous manufacturing, the increase in exports was sufficient to change the sign of the trade effect.

It thus seems difficult to attach much credence, at the two-digit level, to the arguments that imports have significantly impacted employment. There are two objections that have been raised to that conclusion. On one hand, proponents of protection have asserted that increases in labor productivity may be associated with import competition; on the other hand, it can be argued that more disaggregated data would tell a different story. 
The first argument -- that increasing imports result in increased rates of labor productivity growth -- is difficult to evaluate. If it is true, it would significantly increase the welfare losses associated with any protectionist measures. It is not, therefore, necessarily an argument in favor of protection. At the two-digit level, however, there does not appear to be any simple relationship between productivity growth rates and imports: a regression of the rate of growth of labor productivity on the rate of growth of imports (from the data in rable 1) yields a negative $(-.03)$ but statistically insignificant coefficient. It seems equally plausible that increased imports might spur domestic entrepreneurs to a greater efficiency, and that industries with slow rates of product:Ivity growth (and therefore above-average rates of increases in price) would be the ones most likely affected by import competition. There is no compelling reason why causation should be the same in all industries. While further research might yield fruitful results in clarifying the relationship between import competition and domestic efficiency, it seems reasonable to conclude that the productivity-import competition argument can go either way and is certainly not well enough documented to serve as a basis for either a free trade or a protectionist case given the present state of knowledge.

The second argument - that two-digit industries are not sufficiently disaggregated -- has more appeal. It should be noted, however, that the more disaggregated the industry, the higher in absolute value the price elasticity of demand facing it is likely to be. To that extent, even where import competition appears to be a significant factor, there is a question about the extent to which protection would result in increased domestic production levels, rather than reduced domestic consumption levels. 
Nonetheless, in an attempt to evaluate the contention, the available data were collected on four-digit subsectors of the two-digit industries: textiles, apparel, leather products, and electrical and electronic equipment. These are the four sectors which are most widely regarded as having experienced significant dislocation due to import competition. Unfortunately, the necessity to obtain price deflators becomes increasingly difficult as the definition of an industry narrows, and the number of subsectors for which it was possible to estimate output, trade and employment levels was not large. Table 2 presents the results.

As can be seen, the variation in employment growth rates across fourdigit industries is, as would be expected, considerably larger than for two-digit sectors. Nonetheless, the general impression remains much the same: demand and labor productivity growth rates, and not imports, have been the dominant factor in affecting rates of employment growth. Of the 42 four-digit industries for which data were available, there were 12 which experienced rates of employment decline in excess of 3 percent. In on $1 y$ one of those was the rate of increase of the import share in excess of 1.33, and that was radio and TV sets, where employment decreased 3.72 percent at a continuous annual rate, while the import share rose at a rate of 3.20 percent. For the four-digit Industry with the most rapid rate of employment decline (electronic recelving tubes), the industry experienced declining demand at a rate of 12.1 percent, increased labor productivity at 7.45 percent, and an increased import share at 1.32 percent. Although the data are not conclusive because of the absence of appropriate data for other subsectors, the evidence seems fairly strong that even at the four-digit level, it cannot be so that protection, or reduction of imports, could in any major part have offset the tendency toward reduced employment levels at the four-digit level. Production growth and demand patterns were far too large relative to the growth rate of imports. 
Table 2

Four-Digit Industry Results

(continuous percentage rates)

SIC

Demand Labor

Code Name

Growth

Productivity

Imports Employment

\begin{tabular}{|c|c|c|c|c|c|}
\hline 2211 & Cotton Weaving Mills & 6.48 & -10.18 & -.56 & -4.26 \\
\hline 2221 & Synthetic Weaving Mills & 1.90 & -.25 & .10 & 1.74 \\
\hline 2231 & Wool Weaving Mills & -10.18 & -2.10 & .22 & -12.07 \\
\hline 2252 & Hosiery Mills, n.e.c. & 2.74 & -5.87 & .57 & -2.57 \\
\hline 2272 & Tufted Carpets \& Rugs & 6.29 & -5.90 & $.0 \%$ & .40 \\
\hline 2281 & Yarn Mills & 3.86 & -1.74 & .03 & 2.15 \\
\hline 2283 & Wool Mills & $-16: 73$ & 1.32 & -.31 & -1.5 .93 \\
\hline 2297 & Combing Plants & 21.54 & -1.2 .28 & 7.59 & 16.86 \\
\hline 2298 & Cordage \& Twine & 5.35 & .06 & -1.20 & 4.19 \\
\hline 2311 & Mens $^{\top} \&$ Boys ${ }^{\prime}$ Suits \& Coats & -.85 & -1.73 & -1.21 & $=3.79$ \\
\hline 2321 & Mens \& Boys' Shirts & 5.06 & -2.55 & -2.38 & .15 \\
\hline 2327 & Mens \& Boys' Pants & .35 & -2.76 & .65 & -1.76 \\
\hline 2328 & Mens \& Boys' Work Clothing & 6.32 &. .1 .47 & .0 .4 .5 & 3.41 \\
\hline 2341 & Womens \& Childrens ' Underweax & .23 & -3.05 & $\therefore .03$ & -2.84 \\
\hline 2342 & Corsets \& Allied Garments & -.30 & -7.20 & -1.33 & -8.84 \\
\hline 2369 & Childrens" Outerwear & 8.30 & -5.08 & -.4 .37 & -1.15 \\
\hline 2386 & Leather \& Sheepskin Clothing & 9.03 & 1.49 & -6.81 & 3.72 \\
\hline 2392 & House Furnishings & .69 & -2.01 & -.12 & -1.45 \\
\hline 3131 & Footwear Cut Stock & -10.28 & 2.99 & -.81 & -8.09 \\
\hline 3161 & Luggage & 7.94 & -5.32 & --1.65 & .95 \\
\hline 3171 & Womens' Handbags & 7.76 & -4.39 & -1.89 & 1.52 \\
\hline 3172 & Personal Leather Goods n.e.c. & 2.26 & -4.95 & -1.03 & -3.72 \\
\hline 3612 & Transformers & -1.38 & -2.24 & -.1 .9 & $-3 . \overline{80}$ \\
\hline 3621 & Motors \& Generators & -1.01 & -.34 & -.86 & -2.23 \\
\hline 3623 & Welding Apparatus & 2.65 & -.23 & -.19 & 2.23 \\
\hline 3624 & Carbon Products & -1.08 & .73 & .35 & .00 \\
\hline 3632 & Household Refrigerators & -2.80 & -3.03 & -.26 & -6.09 \\
\hline 3633 & Household Laundry Equipment & .80 & -4.13 & -.02 & -3.34 \\
\hline 3634 & Housewares \& Fans & 5.82 & -5.83 & $.0 \%$ & .01 \\
\hline 3635 & Vacuum Cleaners & 6.82 & -5.26 & .07 & 1.59 \\
\hline 3636 & Sewing Machines & 1.51 & 1.98 & 1.31 & 4.79 \\
\hline 3639 & Household Appliances n.e.c. & 7.51 & -5.72 & -2.86 & -1.07 \\
\hline 3641 & Lamps & -.20 & -2.32 & -.21 & -2.73 \\
\hline 3643 & Current Carrying Wiring Devices & 1.51 & -.30 & -1.22 & .00 \\
\hline 3644 & Non-current Carrying Wiring & & & & \\
\hline & Devices & -2.11 & .15 & .02 & -1.96 \\
\hline 3651 & Radio \& TV Sets & 9.18 & -9.70 & -3.20 & -3.72 \\
\hline 3652 & Phonographs & 10.51 & -11.21 & -.19 & -.90 \\
\hline 3671 & Electronic Receiving Tubes & -12.12 & -7.45 & -1.32 & -2.0 .88 \\
\hline 3684 & Semi-conductors & 19.85 & -15.60 & -1.82 & 2.43 \\
\hline 3691 & Storage Batteries & 5.83 & -4.29 & -.02 & 1.51 \\
\hline 3692 & Primary Batteries & .4 .29 & -2.26 & -.28 & 1.76 \\
\hline 3693 & $\mathrm{X}$-ray Apparatus & 15.26 & -1.10 & -.66 & 13.52 \\
\hline
\end{tabular}




\section{WHO GAINS AND WHO LOSES FROM PROTECTION?}

In light of the evidence that protection could not in any najor way reverse the employment trends in most declining industries, it is of interest to ask where protectionist pressures originate, and who gains from protection. There is, first, the question of the division of whatever spoils there are between labor and capital. As Magee has neatly documented, owners and workers have generally lobbied on the same side of protectionist: legislation. If labor is relatively mobile contrasted with capital, international trade models would suggest that the gains to capital from protection would exceed the gains to labor. ${ }^{1}$

There is another, somewhat related; aspect, which may be partly unique to the United States. That is, a number of industries have relocated geographically within the United States. Consider, for example, the data in Table 3. They indicate the number of persons employed in the textile industry (SIC 22) and the apparel industry (SIC 23) in two major regions of the United States, along with total U.S. employment. ${ }^{2}$ is can be seen, the fortunes of the two have been quite different, as employment in New England and the Middle Atlantic States has dropped sharply since 1959, while employment in the South Atlantic states and the East South Central region has grown continuously in the apparel industry, and been rising or fairly steady in the textile industry. If one takes the states in the

${ }^{1}$ See, for example, Mayer. There also questions about the interindustry impacts of protection. For example, insofar as the multifiber agreenent has raised the European and American price of textiles above that East Asia, one would anticipate that East Asia would gain a competitive advantage in the export of apparel. Similar questions must surely be raised about protection of steel

2 The New England and Middle Atlantic States include: Maine, New Hampshire, Vermont, Massachusetts, Connecticut, Rhode Island, New York, New Jersey and Pennsylvania. South Atlantic and East South Central include: Delaware, Maryland, Virginia, North Carolina, South Carolina, Georgia, Florida, Kentucky, Tennessee, Alabama and Mississippi. 
Table 3

Employment in the U.S. Textile and Apparel Industries By Region, Various Dates

(thousands of employees)

$\underline{\text { Textiles }}$

1959

1965

1970

1976
New England and Middle Atlantic

$300.2 \quad(32.3)$

$249.6 \quad(28.0)$

218.5 (23.6)

$175.6 \quad(20.1)$
South Atlantic and

East South Central

$571.7 \quad(61.6)$

$59.5 .2(66.8)$

$652.2(70.5)$

$645.1 \quad(73.7)$
U.S. rotal

928.8

891.5

92.4 .5

875.8

\section{Appare1}

1959

$\begin{array}{ll}695.6 & (56.2) \\ 657.3 & (50.1) \\ 574.9 & (42.9) \\ 432.3 & (34.0)\end{array}$

$271.2 \quad(21.9)$

$\mathrm{x}, 238.7$

1965

1970

1976

$432.3 \quad(34.0)$

$366.8 \quad(28.0)$

$1,311.8$

$429.2 \quad(32.0)$

$1,341.4$

$472.8 \quad(37.2)$

$1,270.6$

Sources: U.S. Department of Commerce, Bureau of the Census, Annual Survey of Manufactures 1959 and 1960, 1964-1965, 1970-1971, and 1975-1976. 
U.S. and partitions them into those in which employment rose and those in which employment fell between 1970 and 1976 in textiles, and sums the gross employment change within each group of states, the resulting number is that there were 29.1 thousand additional jobs in the states with gains, and 77.8 thousand less jobs in the states which experienced losses. In apparel, there were 103.2 new jobs in states with gains, and 173.2 losses in states where employment fell.

All of these figures indicate an additional dimension to the probler of declining industries in the United States: industries are relocating in areas where labor costs are lower at the same time as they are contracting nationally. As Table 3 vividly indicates, the lost employment in New England and the Middle Atlantic States was more than offset, at least: until 1970, by gains in employment in the South Atlantic and East South Central States.

These data point up an additional consideration of some importance if the dislocation costs of job losses are the motive behind protection: the pace of relocation may increase or decrease with additional protection from imports. In one study on the subject, Isard argued that protection in the textile industry raised profits, which in turn raised the rate at which automated machinery replaced labor in that industry. To the extent that increased profits are also an inducement for expansion, and expansion occurs in parts of the country other than where existing plants are located, the presumption that protection can do anything to reduce the rate of dislocation in the states losing employment is still further weakened.

Little is known about the ways in which firms and industry structure actually respond to shifts in demand, whether generated by protection from imports or other phenomena. Taking a neutral assumption, that the rate of 
shift of the share of employment between north and south is independent of the height of protection (and presumably therefore the profilability of the industry, although this latter is questionable unless it is assumed that the wage is competitively determined and that the supply of labor to the textile industry is perfectly elastic), the data in Table 3 suggest that, even had protection in the textile industry been sufficient to maintain employment in 1976 at its 1970 level, job losses in the north would only have been reduced from 42.9 million to 32.7 million, while employment in the south would have increased by 29.1 million. 'Jhe Figures for apparel are even more striking, as the south in fact increased rextile employment in the face of a declining national total. If, as seems to be the case, it is the dislocation of fob losses that is the principal concern of those advocating protection, regional consideraticas in the United States would suggest that, at least in textiles and apparel, a large number of additional jobs would have to be created (jin the South) per job loss prevented in New England. The illustrative numbers for textiles (which, it should be remembered, are based on the neutral but unsubstantiated assumption that the share of the south was independent of the absolute size of national employment) suggest that prevention, even if feasible, of 10.2 thousand job layoffs in New kngland could have been achieved only with 29.1 thousand additional jobs in the south. Thus, three additional persons would have started employment in the south, in an admittedly uneconomic use of scarce resources, to save one job in the north.

These numbers are illustrative, and nothing more. The dynamics of locational choice within industries are not well understood, and until they are, it will be difficult to carry the argument further. It should 
be noted, however, that there was some (not necessarily highly effective) protection accorded to the American textile industry during the 1970 to 1976 period. Given the regional shift that in fact occurred, the observed changes in employment location obviously reflect, at least somewhat, the degree to which job losses in the north were avoided: given that the industry continued its relocation to the south, the decline in national employment that was prevented went in considerable proportion to increased employment opportunities in the south.

\section{CONCLUSIONS}

Despite the intuitive appeal of the notion that increased imports must have been a significant determinant of the "impact effect" in layoffs and job losses in the United States, examination of the evidence does not support the case to any substantial degree. Not only do imports into the United States, even in the industries where they are believed to be harming American workers, constitute relatively small fractions of total domestic consumption, but in addition, rates of change of demand and of labor productivity growth have been quantitatively larger than changes in the import share.

Moreover, there are important questions as to the extent that protection, even if it were intensified, would prevent job layoffs. On one hand, there is some evidence that higher profitability may lead to more rapid investment, which in turn may result in a more rapid rate of change in technique toward more capital-intensive methods. As such, it may be capital, and not labor, which gains more by protectionist measures. In 
addition, the fact that Industries can relocate regionally in the United States further diminishes whatever link there might be between import. levels and job layoffs in particular industries. At least some part of whatever additional employment might result from protection accrues to regions and states which are not experiencing job losses: an important: question is the extent to which protection might in fact increase the rate of industrial relocation.

While there are hardships involved with any job termination and necessity to relocate either occupationally or geographically, it is not: evident that those hardships are more intense when layoffs are "caused" by one factor, such as iroport competition, than by any other (such as regional relocation, a declining industry, or a pooxly managed firm). For the United States, a strong case can be made that social policy toward those losing jobs should be indeperdent of whether the lost jobs are attributable to imports or not. Not only is it conceptually difficult, if not impossible, to ascertain causation, but even if one could make statements such as that fraction $x_{1}$ of job losses were "caused" by Import competition, while fraction $\left(1-x_{1}\right)$ were a consequence of other factors, it seems implausible that a method for identifying which $x_{1}$ of the newly unemployed should be treated differently.

Perhaps even more importantly, the avallable evidence for the United States seems convincing that job turnovers have been more a consequence of the process of economic growth than they have been of imports. The economic costs of "saving jobs lost due to imports", no matter how done, would be very high per job saved. Not only theory, but the available empirical evidence, supports the view that trade policy is not an appropriate instrument to deal with even the "impact effect" on employment. 


\section{REFERENCES}

Baldwin, Robert E. 1971 "Determinants of the Comnodity Structure of U.S. Trade", American Economic Reviev, ,Narch.

Bale, Malcolm D. 1977 "Estinates of Trade Displacement Costs for U.S. Workers", Journal of International Economics , May.

Branson, William and Monoyios, Nikolaos 1977 "Factor Imputs in U.S. Trade", Journal of International Economics, May.

Frank, Charles R. Jr. 1977 Foreign Trade and Domestic Aid, Brookings Institution.

Isard, Petex 1973 "Employment Impacts of Textile Inports and Ynvest:ment: A Vintage-Capital Model", American Economic Review June.

Krueger Anne 0. 1979a "LDC Manufacturing Production and Implications

- for OECD Comparative Advantage", in Irving Leveson and Jimny W. Wheeler, editors Western Economies in Transition: Structural Change and Adjustment Policies in Industrial Countries, Westview Press: Boulder, CO, (C) the Hudson Institute.

Krueger, Anne 0. $1979 \mathrm{~b}$ "She Impact of Foreign Trade on Finployment in U.S. Industry" in John Black and Brian Hindley, editors, Current Issues in Commercial Policy and Diplomacy, Macmillan Press, London.

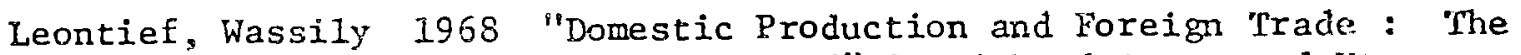
American Capital Portion Reexamined" in Richard Caves and Harry Johnson, Readings in International Economics, Richard D. Jwwin, Inc.: Homewood, Illinois.

Magee, Stephen P. 1978 "Three Simple Tests of the Stolper-Samuelson Theorem", The University of T'exas at Austin Graduate School of Business, Working Paper 78-73, October.

Mayer, Wolfgang 1974 "Short-Run and Long-Run Equilibrium For a Small Economy", Joumal of Political Economy, Sept./Oct. 